\title{
Comparison of Flesh Colour Assessment Methods for Wild Brown Trout (Salmo trutta macrostigma), Farmed Rainbow Trout (Oncorhynchus mykiss) and Farmed Atlantic Salmon (Salmo salar)
}

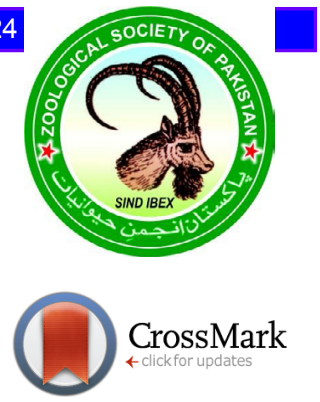

\author{
Nihat Yeşilayer* \\ Department of Aquaculture, Faculty of Agriculture, Tokat Gaziosmanpaşa University, \\ 60240 Tokat, Turkey
}

\begin{abstract}
A B S T R A C T
Red/pink flesh colour is the most distinctive visual quality characteristic in wild brown trout (WBT), farmed Atlantic salmon (FAS) and farmed Rainbow trout (FRT). The study was conducted on three fish species to investigate the relationship between total carotenoid concentration (TCC) and flesh colour, determined by visual and colorimetric methods, of three fish species. Linear relationships were observed between CIELAB colour measurements (lightness-L*, redness-a*, yellowness-b*, hue- $\mathrm{H}^{\circ}$ ab and chroma$\mathrm{Cab}$ ), DSM SalmoFan card scores and TCCs. The redness (a*) was mostly correlated with TCC of the fish fillets. The FRT group had the highest TCC $\left(9,75 \mathrm{mg} \mathrm{kg}^{-1}\right)$ compared to the other two species. However, DSM SalmoFan ${ }^{\mathrm{TM}}$ card score was higher in FAS group $(28,98)$ than that measured in FRT and WBT. The TCC of trout flesh linearly increased with increasing the $\mathrm{a}^{*}$ and decreasing the $\mathrm{L}^{*}$ values. The marketing of FRT produced in Turkey has difficult in the world due to the pale flesh colour demand of the consumers. This study showed that SalmoFan Card ${ }^{\mathrm{TM}}$ scores could be practical and reliable tool for Salmonid farms as compared to other methods.
\end{abstract}

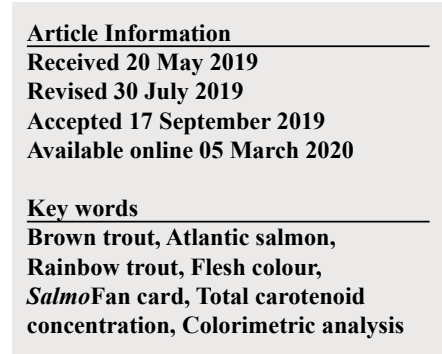

\section{INTRODUCTION}

$\mathrm{F}$ lesh colour, especially a red/pink, is the most significant visual quality parameter in salmonids. The specific pink colour is the first trait that consumers observe when purchasing salmonids (Anderson, 2000). Although flesh colour does not directly impact on flesh quality, consumers usually prefer redder salmonids, considering it as a sign of fresher and better taste.

The rainbow, brown trout and Atlantic salmon are commonly cultured and consumed salmonid species both in Turkey and in the world because of their favourable taste and high availability in markets. The worldwide production capacities of Atlantic salmon, rainbow and brown trout are 2 248000,814091 and 29604 tons, respectively (Harlığlu, 2017; FAO, 2018). Turkey produces $12.82 \%$ of global aquaculture production of rainbow trout. The wild brown trout belongs to the genus Salmo and it can be distinguished from other species with its dark red spots and brownishyellow colour. Turkey and Europe are the natural habitats of brown trout. Turkish and European trout are the most preferred trout of the consumers due to their unique aroma

\footnotetext{
* Corresponding author: nihatyesilayer@gmail.com 0030-9923/2020/0003-1007 \$ 9.00/0

Copyright 2020 Zoological Society of Pakistan
}

(Yeşilayer and Genç, 2013). Although a pale colour of flesh is a common characteristic of trout, an unusual yellow pigmentation has been observed in trout harvested in several Turkish fish farms. The yellow pigmentation in trout have recently increased and resulted in significant economic losses for the fish industry, since, trout with yellow flesh colour, although healthy, is not preferred by the consumers.

Carotenoids are responsible for formation of typical salmonid flesh colour (Storebakken and No, 1992), and may also be involved in yellow pigmentation. The increase in flesh-coloured trout farming, resulted in a significant growth in trout exports to Europe and Japan, which led to a financial relief for rainbow trout producers. Salmonids are unable to synthesize carotenoids de novo, therefore they have to get the carotenoid through feeding with special diets. However, carotenoids may be subjected to some chemical modifications before accumulation in the muscles (Ando et al., 1990). Fish are mostly fed with compound feeds containing carotenoids. Canthaxanthin and astaxanthin are the common supplements used in salmonid diets to form the pink flesh colour (Torrissen, 1985). Astaxanthin is an expensive carotenoid and typically constitutes almost one-fifth of total feed cost and around $8 \%$ of total production cost (Torrissen, 1995). The most significant challenge of commercial fish farms is to 
meet the flesh colour demands of the consumers with a minimum cost. The goal is to maintain a balanced diet in order to obtain desired quality level.

Scientists employ various chemical and instrumental methods to evaluate flesh colour, however farmers, feed producers and processing industry use colour cards as the measure of fish pigmentation. The purpose of this study was to compare flesh colours of three Salmonid fish species determined by visual, colorimetric and chemical methods.

\section{MATERIALS AND METHODS}

\section{Sample preparation}

Fresh (farmed rainbow trout, FRT and farmed Atlantic salmon, FAS) and frozen fish (wild brown trout, WBT) samples were used in the analyses. The WBT in harvest weight were caught with a casting net in Munzur River, Tunceli $(n=20)$. The FRT cultivated in net cages at fish farms (Özbarutcu and Alpoğlu Aquaculture, Tokat, Turkey) in Almus Dam Lake were harvested ( $n=$ $20)$. The cultivated rainbow trout was fed on a trout diet supplemented by commercial carotenoid (astaxanthin $50 \mathrm{mg} \mathrm{kg}^{-1}$ ) for 3 months before harvest. The fresh FAS (imported Salmon) were obtained $(n=20)$ from the fish market of Tokat province, Turkey. Samples of WBT were transported to laboratory within isothermic fish boxes where they were packed in plastic bags and stored at $-30{ }^{\circ} \mathrm{C}$ until the analyses. Frozen samples were thawed overnight at refrigerator $\left(+4{ }^{\circ} \mathrm{C}\right)$ prior to the analyses.

\section{Colour measurements}

The fish were first cut from the gills, and then were immediately placed in crushed ice added water in the tank. The fish were randomly sampled from fish groups, filleted and cut anterior to dorsal including adipose fins. The flesh colour analyses were conducted on the interior of right dorsal fillet. Visual flesh colour assessments were carried out by using DSM Salmo Fan $^{\mathrm{TM}}$ cards (DSM, Basel, Switzerland). The DSM Salmo Fan ${ }^{\mathrm{TM}}$ scale on the fan ranged from 20 (very pale red) to 34 (very intense red) where 20 indicates no visible pigmentation (Foss et al., 1984). The DSM Salmo $\operatorname{Fan}^{\mathrm{TM}}$ (SF) is a further improvement of the Roche Color Card (RCC) and is commonly used for colour assessments of salmonid flesh (Forsberg and Guttormsen, 2006a).

Ten panellists were selected to avoid colour blindness. The panellists were asked to choose the most appropriate tone among the colour cards. Visual colour assessment as suggested in colour cards was performed on white colour tables under enlightened (with white fluorescent light) laboratory conditions with no sunlight. After visual assessment, the same samples $(n=20)$ were underwent colorimetric measurements and total carotenoid concentration (TCC) analyses. The room temperature during the analyses was maintained at $20^{\circ} \mathrm{C}$.

Colorimetric measurements were conducted at the Aquaculture Laboratory of Tokat Gaziosmanpaşa University. Colours of fillet samples were assessed with a Tristimulus colorimeter (Minolta Chroma Meter, CR-300 Minolta, Osaka, Japan) which measures light reflection from the flesh in comparison to a standard calibration plate. The colour parameters measured were lightness $\left(\mathrm{L}^{*}\right)$, red-green chromaticity $\left(\mathrm{a}^{*}\right)$ and yellow-blue chromaticity $\left(b^{*}\right)$ as recommended by the International Commission on Illumination (CIE, 1978). The colour measurements were conducted on the right side of each fish fillet. The instrument was placed on the flesh and triplicate measurements were taken at the filleted section. The $a^{*}$ value represents the redness and the $b^{*}$ value represents the yellowness of the flesh. The chroma $\left(\mathrm{C}_{\mathrm{ab}}{ }^{*}\right)$ and hue $\left(\mathrm{H}^{\mathrm{o}}{ }_{\mathrm{ab}}\right)$ angle were calculated using the $\mathrm{a}^{*}$ and $\mathrm{b}^{*}$ values. The chroma is the expression of intensity and clarity of the colour and is expressed by the following equation (Hunt, 1977);

$$
\mathrm{C}_{\mathrm{ab}} *=\left(\mathrm{a}^{* 2}+\mathrm{b}^{* 2}\right)^{1 / 2} \quad \text {... Eq. } 1
$$

The hue angle is used to define the relationship between the redness and the yellowness of the fillet and is calculated by the following equation;

if $\mathrm{a}^{*}>0^{\circ}$, then $\mathrm{H}_{\mathrm{ab}}{ }^{\mathrm{o}}=\tan ^{-1}\left(\mathrm{~b}^{*} / \mathrm{a}^{*}\right) \quad$...Eq. 2

if $\mathrm{a}^{*}<0^{\circ}$, then $\mathrm{H}_{\mathrm{ab}}^{\mathrm{o}}=180+\tan ^{-1}\left(\mathrm{~b}^{*} / \mathrm{a}^{*}\right) \quad \ldots$ Eq. 3

The hue value is an angular measurement where $0^{\circ}$ indicates the red hue; and $90^{\circ}$ indicates the yellow hue (Nickell and Bromage, 1998; Yeşilayer et al., 2011).

The skin and bones of the fish fillets $(n=20)$ were removed. The muscle samples were homogenized with a homogenizer and sub-samples of approximately 2-3 g were taken for analysis and then transferred to $100 \mathrm{ml}$ volumetric flasks. The TCC analyses were replicated three times. The total carotenoid in the fish flesh was determined by a method modified after Foss et al. (1984) and Skrede and Storebakken (1986). Muscle samples were extracted two times with acetone $(20 \mathrm{ml}+20 \mathrm{ml})$. This process was repeated three times until obtaining colourless minced flesh. Extracts were centrifuged at $5000 \mathrm{rpm}$ for $3 \mathrm{~min}$ and then stored for $24 \mathrm{~h}$ at $4{ }^{\circ} \mathrm{C}$ in a refrigerator. Extracts were measured by a UV-VIS spectrophotometer (Model T60U, PG Instruments UV-VIS spectrophotometer) using extinction coefficients ( $\mathrm{E}_{\% 1,1 \mathrm{~cm}}$ ) of 1900 for astaxanthin and canthaxantin, $475 \mathrm{~nm}$ in acetone (Saito and Regier, 1971; Foss et al., 1984; Skrede and Storebakken, 1986). All colour analyses were performed on 20 samples of each fish species.

\section{Statistical analysis}

The mean \pm standard errors (SE) of all the data were calculated. The Anderson-Darling-Levene test was used 
to control the homogeneity of variance and normality of the data. Tukey multiple-range and analysis of variance (ANOVA) tests were used to detect the differences $(\mathrm{P}<0.05)$ in total carotenoid concentrations, CIELAB colour measurements, and the DSM Salmofan ${ }^{\mathrm{TM}}$ card scores among fish species. All statistical analyses were carried out by using the MINITAB Release 13.1 Statistical Analysis Software for Windows, Version 10.0.1 (Minitab Inc., Chicago, Illinois, U.S.A.). A regression analysis (RA) was conducted to determine the relationships among mean values of CIE parameters of colour, the DSM Salmo Fan ${ }^{\mathrm{TM}}$ card scores and the total carotenoid concentrations ( $\mathrm{mg} \mathrm{kg}$ 1) $(\mathrm{p}<0.01)$.

\section{RESULTS}

Visual colour scores and total carotenoid concentration (TCC)

Mean colour card scores of the flesh fillet of the salmonids (salmon, trout) are shown in Table I. The card scores increased in FAS and FRT fed with feed containing carotenoid. The difference in card scores between salmonid groups was significant $(\mathrm{P}<0.05)$. The best visual scores were obtained from the FRT, FAS and WBT groups, respectively. The colour card scores ranged from 20 to 32 in salmonid fish groups. The mean TCC for FRT and FAS flesh was significantly $(\mathrm{P}<0.05)$ higher than that in WBT.

Table I. Scores of color cards (DSM SalmoFan ${ }^{\mathrm{TM}}$ ) and total carotenoid concentrations $\left(\mathrm{mg} \mathrm{kg}^{-1}\right)$ for salmonid fish.

\begin{tabular}{llll}
\hline Colour analysis & WBT & FRT & FAS \\
\hline DSM Salmo Fan card & $21.38 \pm 0.31^{\mathrm{b}}$ & $28.33 \pm 0.13^{\mathrm{a}}$ & $28.98 \pm 0.26^{\mathrm{a}}$ \\
${\text { TCC } \mathrm{mg} \mathrm{kg}^{-1}}^{4}$ & $4.20 \pm 0.28^{\mathrm{b}}$ & $9.75 \pm 0.03^{\mathrm{a}}$ & $8.68 \pm 0.09^{\mathrm{a}}$ \\
\hline
\end{tabular}

Value (mean \pm standard error of data) with different superscript in the same row is significantly different (one way ANOVA and Tukey's multiple-range test, $p<0.05$ ). TCC, Total carotenoid concentration. WBT, Wild brown trout; FRT, Farmed Rainbow trout; FAS, Farmed Atlantic salmon.

\section{Colour parameters of fillets}

The CIELab colour parameters for the flesh of Salmonid groups were presented in Table II. In contrast to higher TCC in fish flesh, the values of $\mathrm{a}^{*}, \mathrm{~b}^{*}$ and $\mathrm{C}_{\mathrm{ab}}{ }^{*}$ parameters were higher in fish fillet. Variations in colour parameters of the fillets can be attributed to a non-uniform distribution of carotenoid in the flesh (Ingle De La Mora et al., 2006; Skrede et al., 1989; Hatlen et al., 1998). The L* value of fillet samples always reduced and the lowest $\mathrm{L}^{*}$ value was obtained in FRT (Table II).

Similar to the carotenoid concentrations, an increase was also observed in $\mathrm{a}^{*}, \mathrm{~b}^{*}$ and $\mathrm{C}_{\mathrm{ab}}{ }^{*}$ values (Table II).
Table II. CIELab Colour parameters $\left(L^{*}, a^{*}, b^{*}, C^{*} b^{*}\right.$ and $\left.\mathbf{H}^{\mathbf{o}} \mathbf{a b}\right)$.

\begin{tabular}{llll}
\hline $\begin{array}{l}\text { Colours } \\
\text { parameters }\end{array}$ & WBT & FRT & FAS \\
\hline $\mathrm{L}^{*}$ & $53.16 \pm 0.56^{\mathrm{a}}$ & $34,69 \pm 0.83^{\mathrm{c}}$ & $41.72 \pm 0.54^{\mathrm{b}}$ \\
$\mathrm{a}^{*}$ & $7.18 \pm 0.52^{\mathrm{b}}$ & $9.88 \pm 0.36^{\mathrm{a}}$ & $8.15 \pm 0.09^{\mathrm{b}}$ \\
$\mathrm{b}^{*}$ & $14.09 \pm 0.73^{\mathrm{b}}$ & $8.87 \pm 0.31^{\mathrm{c}}$ & $17.04 \pm 0.25^{\mathrm{a}}$ \\
$\mathrm{Cab}^{*}$ & $14.74 \pm 0.80^{\mathrm{b}}$ & $13.26 \pm 0.44^{\mathrm{b}}$ & $18.90 \pm 0.23^{\mathrm{a}}$ \\
$\mathrm{H}^{\mathrm{o}} \mathrm{ab}$ & $65.63 \pm 1.88^{\mathrm{a}}$ & $41.80 \pm 0.74^{\mathrm{b}}$ & $64.37 \pm 0.42^{\mathrm{a}}$ \\
\hline
\end{tabular}

Value (mean \pm standard error of data for triplicate groups) with different superscript in the same row is significantly different (one way ANOVA and Tukey's multiple-range test, $\mathrm{P}<0.05$ ); WBT, Wild brown trout; FRT, Farmed Rainbow trout; FAS, Farmed Atlantic salmon.

The $\mathrm{a}^{*}$ (red pigment) values of FRT group were found to be significantly different $(\mathrm{P}<0.05)$ from WBT and FAS groups. The highest $\mathrm{a}^{*}$ values were obtained in FRT and followed by FAS and WBT, respectively. The yellow pigment values $\left(b^{*}\right)$ of the fish fillets were also significantly $(\mathrm{P}>0.05)$ different between the fish species. The highest $\mathrm{b}^{*}$ values were obtained in FAS fed with carotenoid containing feed (Table II). The $\mathrm{a}^{*}$ and $\mathrm{b}^{*}$ parameters basically depend on TCC of the flesh, but because of more intense redness, corresponding $\mathrm{H}^{\circ}$ ab values exhibited a decrease with increasing carotenoid concentration in the flesh.

WBT and FAS groups presented higher hue angles $\left(\mathrm{H}^{\mathrm{o}} \mathrm{ab}\right)$ than FRT. $\mathrm{H}^{\mathrm{o}} \mathrm{ab}$ angles which define the redness were observed in FRT. The higher $\mathrm{a}^{*}$ and lower $\mathrm{H}^{\mathrm{o}} \mathrm{ab}$ values were found for FRT. The highest Chroma $\left(\mathrm{C}_{\mathrm{ab}}{ }^{*}\right)$ value was found in FAS and the difference in $\mathrm{C}_{\mathrm{ab}} *$ values between Salmonids were significant $(\mathrm{P}>0.05)$.

The relationship among colour assessment methods

All flesh colour parameters were highly correlated to flesh TCC in Salmonids. The results of regressions analysis between scores of colour cards for the fillets and TCC are shown in Figure 1.

The regression equations between SalmoFan Card ${ }^{\mathrm{TM}}$ scores and $\mathrm{a}^{*}$ values were as follows;

SalmoFan Card ${ }^{\mathrm{TM}}(\mathrm{WBT})=1.0649 \times \mathrm{TCC}+16.908$ $\left(\mathrm{R}^{2}=0.896, \mathrm{p}<0.01\right) \quad \ldots$ Eq. 4

SalmoFan Card ${ }^{\mathrm{TM}}(\mathrm{FRT})=9.2083 \times$ x TCC -61.397 $\left(\mathrm{R}^{2}=0.896, \mathrm{p}<0.01\right) \quad \ldots$... 5

SalmoFan Card ${ }^{\mathrm{TM}}(\mathrm{FAS})=2.5809 \times \mathrm{TCC}+6.584$ $\left(\mathrm{R}^{2}=0.909, \mathrm{p}<0.01\right) \quad \ldots$ Eq. 6

SalmoFan Card ${ }^{\mathrm{TM}}(\mathrm{WBT})=0.1487 \mathrm{x}^{* 2}-1.3557 \mathrm{x} \mathrm{a}^{*+}$ $23.297\left(\mathrm{R}^{2}=0.968, \mathrm{p}<0.01\right) \ldots$ Eq. 7

SalmoFan Card ${ }^{\mathrm{TM}}($ FRT $)=-1.5987 \times \mathrm{a}^{* 2}+94.017 \times \mathrm{a}^{*}$ $-1370\left(\mathrm{R}^{2}=0.961, \mathrm{p}<0.01\right) \quad \ldots$ Eq. 8

SalmoFan Card $^{\mathrm{TM}}(\mathrm{FAS})=0.2322 \mathrm{x} \mathrm{a}^{* 2}-1.1954 \mathrm{x} \mathrm{a}^{*}$ $+23.257\left(\mathrm{R}^{2}=0.937, \mathrm{p}<0.01\right) \quad \ldots$ Eq. 9 


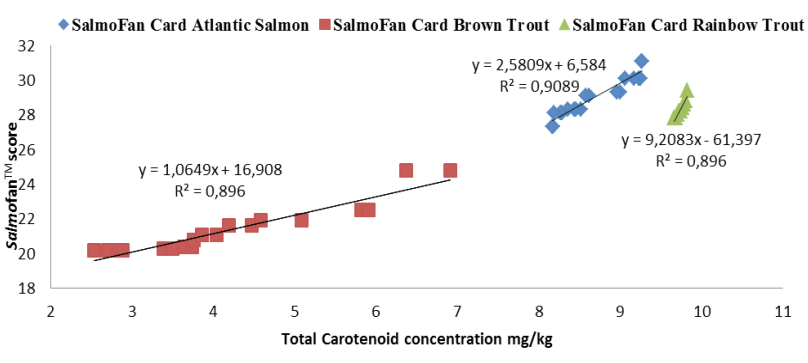

Fig. 1. Regression analysis between the total carotenoid concentration and DSM SalmoFan card scores.

The regression analyses between the TCC and colour parameters were summarized in Table III. Positive correlations were found between TCC and $\mathrm{a}^{*}, \mathrm{~b}^{*}$ and $\mathrm{C}_{\mathrm{ab}}{ }^{*}$ values, while a negative correlation was observed between $\mathrm{L}^{*}$ and $\mathrm{H}^{\circ}$ ab values. The linear modelling between colour parameters and TCC was:

$$
\begin{gathered}
\text { Colour parameter }(\mathrm{cc})=[ \pm \mathrm{A} \times(\mathrm{TCC}) \pm \mathrm{B}] \\
\text { Hue }=\left[ \pm \mathrm{A} \times\left(\mathrm{TCC}^{2}\right) \pm \mathrm{B} \times \mathrm{TCC} \pm \mathrm{C}\right] \\
\text { Colour parameter }=\left[ \pm \mathrm{A} \times\left(\mathrm{a}^{*}\right) \pm \mathrm{B}\right]
\end{gathered}
$$

The intensity in redness increased linearly with increase in TCC. In contrast, the hue angle $\left(\mathrm{H}^{\circ} \mathrm{ab}\right)$ decreased in all groups with increasing TCC levels. A polynomial relationship was observed between Hue values and TCCs. Likewise, a linear relationship was obtained between the $b^{*}$ (yellow pigment) and $a^{*}$ (redness) values of fishes.

Table III. Regression analysis between the TCC and color parameters of salmonid fish.

\begin{tabular}{llll}
\hline Models $^{\mathrm{x}}$ & $\mathrm{R}^{2}$ & Groups & $\mathrm{P}$ \\
\hline $\mathrm{L}=-1.794 \times \mathrm{TCC}+61.262$ & 0.84 & WBT & $* *$ \\
$\mathrm{~b}^{*}=1.4883 \times \mathrm{TCC}+6.7462$ & 0.94 & $* *$ \\
$\mathrm{a} *=1.5449 \times \mathrm{TCC}+0.0735$ & 0.91 & $* *$ \\
$\mathrm{H}^{\mathrm{o}} \mathrm{ab}=1.45 \times \mathrm{TCC}-19.23 \mathrm{TCC}+121.32$ & 0.97 & $* *$ \\
$\mathrm{~b}^{*}=1.2905 \times \mathrm{a}^{*}+4.8231$ & 0.84 & $* *$ \\
$\mathrm{~L}=55.428 \times \mathrm{TCC}-505.78$ & 0.95 & $\mathrm{FRT}$ & $* *$ \\
$\mathrm{~b}^{*}=21.08 \times \mathrm{TCC}-196.35$ & 0.96 & $* *$ \\
$\mathrm{a}^{*}=28.144 \times \mathrm{TCC}-264.12$ & 0.96 & $* *$ \\
$\mathrm{H}^{\mathrm{o}} \mathrm{ab}=125.45 \times \mathrm{xCC}-2382.8 \mathrm{TCC}+11349$ & 0.96 & $* *$ \\
$\mathrm{~b}^{*}=0.7275 \times \mathrm{a}^{*}+1.694$ & 0.94 & $* *$ \\
$\mathrm{~L}=-5.2405 \times \mathrm{TCC}+87.196$ & 0.85 & $\mathrm{FAS}$ & $* *$ \\
$\mathrm{~b}^{*}=2.3339 \times \mathrm{TCC}-3.2113$ & 0.77 & $* *$ \\
$\mathrm{a}=0.9848 \times \mathrm{TCC}-39.56$ & 0.98 & $* *$ \\
$\mathrm{H}^{\mathrm{o}} \mathrm{ab}=5.35 \times \mathrm{TCC}-96.89 \mathrm{TCC}+501.89$ & 0.92 & $* *$ \\
$\mathrm{~b}^{*}=2.4302 \times \mathrm{a}^{*}-2.7655$ & 0.83 & $* *$ \\
\hline
\end{tabular}

${ }^{x}$ Fillet values TCC, Total carotenoid concentration $* *$ : $p<0.01$; WBT, Wild brown trout; FRT, Farmed Rainbow trout; FAS, Farmed Atlantic salmon.

\section{DISCUSSION AND CONCLUSIONS}

Flesh colour in salmonid fishes is primary of the most significant visual quality parameter. Consumers usually prefer redder salmonid fishes, considering the signs of fresher and better taste. The practical method of observe on reddish salmonid fish flesh is color cards. Visiual colour assessments may be practiced by the use of color charts such as DSM SalmoFan Card ${ }^{\mathrm{TM}}$. Such assessments represent crude measures to characterize and classify pigmentation of fish flesh, primarily for the use by fish farmers, fish feed producers, processing industry and marketing organizations. The degree of precision in color determination is relatively low due to influences of illumination, individual abilities to distinguish colors, and qualities of the objects surface (Bjerkeng, 2000).

The DSM SalmoFan Card $^{\mathrm{TM}}$ colour card scores ranged over 14 red colours with varying intensity of redness. SalmoFan Card ${ }^{\mathrm{TM}}$ is a further improvement of the Roche colour card (RCC) for salmonids and widely used for colour assessment of salmonid flesh. The relationship between RCC and SalmoFan Card ${ }^{\mathrm{TM}}$ scores was reported as: SalmoFan Card ${ }^{\mathrm{TM}}=2 \mathrm{RCC}-3$ (Forsberg and Guttormsen, 2006b). Smith et al. (1992) indicated that a visual score (RCC) of 13 or greater was an acceptable colour score for marketable fish. Visual card scores of $\geq 27$ in FAS were considered to be suitable for marketable fish. Forsberg and Guttormsen (2006b) reported that SalmoFan Card ${ }^{\mathrm{TM}}$ scores of FAS (5-6 kg) were between 28 and 29. Johnston et al. (2006) found that total carotenoid pigment concentrations were higher in farmed trout compared to wild Atlantic salmon. In contrast, mean SF score of flesh was higher than 28 in wild Atlantic salmon, and no significant difference was observed between groups. Different experiments have seen a significant linear correlation between SalmoFan ${ }^{\mathrm{TM}}$ score and flesh TCC. Consumer's willingness to spend more money on a fillet increased when comparing salmon scoring a 32 on a the $\mathrm{SalmoFan}^{\mathrm{TM}}$ to those scoring 27 or lower, however seen no difference in preference when comparing fish scoring from 27-29 on the fan (Steine et al., 2005). Similar to the average values of FRT (28, 33) determined in this study, Storebakken et al. (2004) reported SalmoFan Card $^{\mathrm{TM}}$ values ranging from 22, 6 to 28,6 in rainbow trout fleshes. Salmon pigmentation depends on the size of fish, and carotenoids accumulate on muscles of salmonids fed with carotenoid added diets as they grown up. The carotenoid accumulation is generally slow in young fish and increase with increasing weights of fish (Bjerkeng et al., 1992). Shortly, the carotenoid saturation point in salmon flesh is dependent on the fish size (Forsberg and Guttormsen, 2006a).

The FRT recently had several marketing problems 
in Turkey due to the pale flesh colour which can easily be solved. The data in this study suggested that DSM SalmoFan Card score of FRT flesh should be at least 27 to meet the customer demand and processing industry on flesh colour.

The mean total carotenoid concentrations in flesh of WBT, FRT and FAS were above $4 \mathrm{mg} \mathrm{kg}^{-1}$. Pigmentation of flesh in all groups mostly depends on increasing carotenoid concentrations of the feed (insects, flies, aquafeeds etc.). Rainbow trout farms in Turkey did not prefer carotenoidcontaining fish feeds. Therefore, fleshes of FRT were colourless and pale. Recent crisis in the Chilean salmon industry has increased the demand for rainbow trout export, which encouraged rainbow trout farmers in Turkey to increase their production. The fish farms started using carotenoid-containing fish feed in line with the demands of EU countries, Russia federation and Japan, and consequently achieved better quality of flesh colour.

The average carotenoid concentrations in the muscles of FRT following 2-6 months of feeding with different diets supplemented with different carotenoid sources were reported between 5 and $10 \mathrm{mg} \mathrm{kg}^{-1}$ (Torrissen and Naevdal, 1984; Torrissen et al., 1989; No and Storebakken, 1992; Yeşilayer and Erdem, 2011). The carotenoid composition, absorb and deposit of salmon flesh varies among species, sizes, genetic structure, metabolic transformation and gender. Physiological and environmental conditions were also reported to significantly impact carotenoid composition (Arai et al., 1987; Bjerkeng, 2000). Carotenoid supplements are the number one driver of cost in salmonid farming. Fish farmer naturally desire to achieve maximum coloration at minimum cost. Bjerkeng (2000) indicated that the quantity of carotenoid added to the feed, feeding time and the structure of feed in addition to the carotenoid source have significant influence on the carotenoid pigmentation. Slaughter conditions that include different temperatures, handling and stress for the salmon, might affect color. Stressful status may not give better fillet color of Atlantic salmon during harvested (Robb et al., 2000).

The TCC of Atlantic salmon flesh reported by Storebakken et al. (1987) and Buttle et al. (2001) ranged from 4 to $8 \mathrm{mg} \mathrm{kg}^{-1}$, which are similar to the findings of current study (Table I). However, the TCC of fish flesh was higher than that reported for WBT (No and Storebakken, 1991). Environmental factors and actual pigment concentrations in addition to the differences in species affect the duration of dietary carotenoid, lipid level, dietary carotenoid level (Torrissen, 1985), weight and sexual maturation (Buttle et al., 2001). In Turkey, triploid rainbow trout are farmed to avoid color degradation due to sexual maturation. Torrissen et al. (1989) noted that 3 to 4 $\mathrm{mg} \mathrm{kg}{ }^{-1}$ of TCC in flesh can be considered as an acceptable TCC level in marketable farmed salmonids based on visual colour impression. Since the carotenoids may fade in flesh during storage and processing, acceptable flesh TCC levels (above $4 \mathrm{mg} \mathrm{kg}^{-1}$ ) must be met in the delivered products to compensate colour deterioration during storage. The TCC of FRT and FAS fleshes of fish species investigated met the desired TCC level.

Astaxanthin and canthaxanthin are the most efficient carotenoids used for salmonid pigmentation (Torrissen et al.,1989; Storebakken and No, 1992) and constitute about $15-20 \%$ of the total feed cost or around $6-8 \%$ of the total production cost (Torrissen et al., 1989). Salmonid diets should be supplemented with canthaxanthin and/or astaxanthin at minimum $20 \mathrm{mg} \mathrm{kg}^{-1}$ dry feed to ensure the pigmentation.

Consumers usually prefer reddish colour in salmonid fishes (Skonberg et al., 1998). Redness is considered as a significant indicator of quality and contributes to the overall enjoyment of cooked salmonid flesh (Sylvia et al., 1995). The cost of carotenoid supplements with a rate of $50 \mathrm{mg} \mathrm{kg}^{-1}$ to diet was found similar to those reported in other studies.

Linear relationships between SalmoFan Card $^{\mathrm{TM}}$ and TCC of fish flesh were also reported by Christiansen et al. (1995) and Buttle et al. (2001), however the findings of many others were not complying with the current findings (Foss et al., 1984; Storebakken et al., 1987; Smith et al., 1992). Christiansen et al. (1995) indicated that astaxanthin concentration at higher astaxanthin levels was better predicted by the colour cards compared to the colour assessment made by the chromameter.

The variations in values of colour parameters might be resulted from non-uniform carotenoid distribution of flesh, discrete measurement points over the fillet surface and the beam reflectance (Hatlen et al., 1998; Ingle De La Mora et al., 2006; Skrede et al., 1989). Instrumental assays are preferred due to the higher objectivity in under variable lighting conditions, despite the low cost and easiness of colour card assessment (Hatlen et al., 1998). Increasing carotenoid concentrations reported to cause higher $\mathrm{a}^{*}, \mathrm{~b}^{*}$ and $\mathrm{C}_{\mathrm{ab}} *$ and lower $\mathrm{L}^{*}$ and $\mathrm{H}^{\circ} \mathrm{ab}$ values (Skrede et al., 1989; Smith et al., 1992; Ingle De La Mora et al., 2006). Since the $\mathrm{a}^{*}$ value indicates the redness, the $\mathrm{a}^{*}$ value usually has the highest correlation with higher carotenoid levels (Bjerkeng, 2000). The factors such as colour measurements of three different species examined and unique colour characteristics of each species should be taken into account during the evaluation of the data.

In the regards to the findings of linear relationship between colour parameters and TCC reported by Ingle De La Mora et al. (2006) and Smith et al. (1992), we 
have observed a similar relation between TCC and colour parameters. The differences among the reports were the mode of relationship obtained. Skrede and Storebakken (1986) and Ingle De La Mora et al. (2006) reported a strong linear relationship between the carotenoid concentrations and $\mathrm{a}^{*}$ and $\mathrm{L}^{*}$ parameters of rainbow trout. However, Smith et al. (1992) reported a polynomial relationship between carotenoid concentrations of coho salmon flesh and $\mathrm{a}^{*}, \mathrm{~b}^{*}$ and $\mathrm{L}^{*}$ parameters. Storebakken et al. (2004) found a linear relationship between carotenoid concentrations of rainbow trout flesh and $\mathrm{a}^{*}$ parameter, whereas the relationship was logarithmic with $b^{*}$ parameter. The differences in reports can be attributed to the differences in carotenoid concentrations of the fish investigated. Furthermore, other factors can be responsible for the variations, such as differences in fish species, size, age, carotenoid amount in diet/bait, dietary pigment sources and proximate composition (Hatlen et al., 1998; Bjerkeng, 2000).

The TCC and Hue value of the groups had a seconddegree polynomial relationship. The increase in TCC concentration up to $5 \mathrm{mg} \mathrm{kg}^{-1}$ sharply decreased the Hue values. However further increases in TCC concentration of trout flesh induced a slight decrease in Hue values. Similar polynomial relationships between TCC and Hue angle were also reported by Hatlen et al. (1998) for arctic char and by Nickell and Bromage (1998) for Rainbow trout. In contrast to the polynomial relationships, Ingle De Mora et al. (2006) reported a negative linear relationship for the same parameters. The Hue $\left(\mathrm{H}^{\mathrm{o}} \mathrm{ab}\right)$ angle value of the FRT $\left(41.80^{\circ}\right)$ which is closer to $0^{\circ}$ than the other two species and the high TCC are the evidences of being more reddish compared to the other two species.

The experts from the export companies stated that fish flesh colour above the DSM SalmoFan Card ${ }^{\mathrm{TM}}$ score of 26 are easier to export and their market value is higher. The same experts and fish farmers described the FRT with $27 \geq$ DSM SalmoFan Card ${ }^{\mathrm{TM}}$ score and $3 \mathrm{~kg} \geq$ weight as high premium. The current study constitutes the first report to the producers and exporters on colour comparisons of three different species. SalmoFan Card ${ }^{\mathrm{TM}}$ scores obtained in the current study could be practical for Salmonid farms and are as reliable as the parameters obtained in other methods. SalmoFan ${ }^{\mathrm{TM}}$ Card scores can be recommended for the colour assessment of fish. The results are particularly important for aquaculture, indicating that trout marketed in Turkey as well as in many parts of the world depend on desired colour formation.

Statement of conflict of interest

The author has declared no conflict of interest.

\section{REFERENCES}

Anderson, S., 2000. Salmon color and the consumer. IIFET 2000 Proceedings. Corvallis, Oregon, USA, pp. 1-3.

Ando, S., Osada, K., Hatano, M. and Saneyoshi, M., 1990. Metabolisma of astaxanthin in muscle and ovary from brook trout, Salvelinus fontinalis. Comp. Biochem. Physiol. B. 96B, 2: 355-359. https://doi.org/10.1016/0305-0491(90)90388-A

Arai, S., Mori, T., Miki, W., Yamaguchi, K., Konosu, S., Satake, M. and Fujita, T., 1987. Pigmentation of juvenile coho salmon with carotenoid oil extracted from Antarctic krill. Aquaculture, 66: 255- 264. https://doi.org/10.1016/0044-8486(87)90111-6

Bjerkeng, B., Storebakken, T. and Liaaen-Jensen, S., 1992. Pigmentation of rainbow trout from start feeding to sexual maturation. Aquaculture, 108: 333-346. https://doi.org/10.1016/00448486(92)90117-4

Bjerkeng, B., 2000. Carotenoid pigmentation of salmonid fishes-recent progress 1. In: Avances en Nutricion Acuicola V Memorias del V. Simposium Internacional de Nutricion Acuicola. 19-22, November, Merida, Yucatan, Mexico, pp. 71-89.

Buttle, L.G., Crampton, V.O. and Williams, P.D., 2001. The effect of feed pigment type on flesh pigment deposition and colour in farmed Atlantic Salmon Salmo salar L. Aquacul. Res., 32: 103- 111. https:// doi.org/10.1046/j.1365-2109.2001.00536.x

Christiansen R., Struksnaes, G., Estermann, R. and Torrissen, O.J., 1995. Assessment of flesh colour in Atlantic salmon, Salmo salar. L. Aquacul. Res., 26: 311-321.https://doi.org/10.1111/j.1365-2109.1995. tb00919.x

C.I.E. 1978. Recommendations on uniform color spaces, color difference equations, psychometric color terms. Supplement No 2 to CIE PublicationNo 15, Colorimetry, Bureau Central de la CIE, Paris. https://doi.org/10.1002/j.1520-6378.1977. tb00102.x

FAO, 2018. The state of world fisheries and aquaculture 2018. Meeting the sustainable development goals. Rome. ISSN 1020- 5489.

Forsberg, O.I. and Guttormsen, A.G., 2006a. A pigmentation model for farmed Atlantic salmon: Nonlinear regression analysis of published experimental data. Aquaculture, 253: 415- 420. https://doi.org/10.1016/j.aquaculture.2005.09.004

Forsberg, O.I. and Guttormsen, A.G., 2006b. Modeling optimal dietary pigmentation strategies in farmed Atlantic salmon: Application of mixed- 
integer non-linear mathematical programming techniques. Aquaculture, 261: 118- 124. https://doi. org/10.1016/j.aquaculture.2006.06.049

Foss, P., Storebakken, T., Schiedt, K., Liaaen-Jensen, S., Austreng, E. and Streiff, K., 1984. Carotenoids in diets for salmonids: 1. Pigmentation of rainbow trout with the individual optical isomers of astaxanthin in comparison with canthaxanthin. Aquaculture, 41: 213- 226. https://doi.org/10.1016/00448486(84)90284-9

Hatlen, B., Jobling, M. and Bjerkeng, B., 1998. Relationship between carotenoids concentrations and colour of fillets of Arctic charr, Salvelinus alpinus (L.), fed astaxanthin. Aquacul. Res., 29: 191202. https://doi.org/10.1111/j.1365-2109.1998. tb01124.x

Harlığlu, A.G. 2017. Comparative study of fatty acid composition of gametes, embryos and larvae of Rainbow Trout, Oncorhynchus mykiss. Pakistan J. Zool., 49: 1803-1808. http://dx.doi.org/10.17582/ journal.pjz/2017.49.5.1803.1808

Hunt, R.W.G., 1977. The specification of colour appearance. 1. Concepts and terms. Color Res. Appl., 2: 55- 68. https://doi.org/10.1002/ col.5080020202

Ingle de la mora, G., Arredondo-Figueroa, J.L., PoncePolofox, J.T., Delos Angeles Barriga-Soca, I. and Vernon-Carter, J.E., 2006. Comparison of red chili (Capsicum annuum) oleoresin and astaxanthin on rainbow trout (Oncorhynchus mykiss) fillet pigmentation. Aquaculture, 258: 487- 495. https:// doi.org/10.1016/j.aquaculture.2006.04.005

Johnston, I.A., Li, X., Vieira, V.L.A., Nickell, D., Dingwall, A., Alderson, R., Campbell, P. and Bickerdike, R., 2006. Muscle and flesh quality traits in wild and farmed Atlantic salmon. Aquaculture, 256: 323- 336. https://doi.org/10.1016/j. aquaculture.2006.02.048

Nickell, D.C. and Bromage, N.R., 1998. The effect of dietary lipid level on variation of flesh pigmentation in rainbow trout. Aquaculture, 61: 237- 251. https:// doi.org/10.1016/S0044-8486(97)00273-1

No, H.K. and Storebakken, T., 1991. Pigmentation of rainbow trout at different water temperatures. Aquaculture, 97: 203-216. https://doi. org/10.1016/0044-8486(91)90265-9

No, H.K. and Storebakken, T., 1992. Pigmentation of rainbow trout with astaxanthin and canthaxanthin in fresh water and sea water. Aquaculture, 10: 123- 134. https://doi.org/10.1016/00448486(92)90237-F

Robb, D.H.F., Kestin, S.C. and Warris, P.D., 2000.
Muscle activity at slaughter: I. Changes in flesh colour and gaping in rainbow trout. Aquaculture, 182: 261-269. https://doi.org/10.1016/S00448486(99)00273-2

Saito, A. and Regier, L.W., 1971. Determination of total carotenoid pigments in trout and salmon flesh. J. Fish. Res. Bd. Can., 28: 509- 512. https://doi.org/10.1139/ f71-071

Skrede, G. and Storebakken, T., 1986. Characteristics of color in raw, baked and smoked wild and pen-reared Atlantic salmon. J. Fd. Sci., 51: 804- 808. https://doi. org/10.1111/j.1365-2621.1986.tb13936.x

Skrede, G., Storebakken, T. and Naes, T., 1989. Color evaluation in raw, baked and smoked flesh of rainbow trout (Oncorhynchus mykiss) fed astaxanthin or canthaxanthin. J. Fd. Sci., 55: 1574- 1578. https://doi. org/10.1111/j.1365-2621.1990.tb03572.x

Skonberg, D.I., Hardy, R.W., Barrows, F.T. and Dong, F.M., 1998. Color and flavor analyses of fillets from farm-raised rainbow trout (Oncorhynchus mykiss) fed low-phosphorus feeds containing corn or wheat gluten. Aquaculture, 166: 269- 277. https:// doi.org/10.1016/S0044-8486(98)00294-4

Smith, B.E., Hardy, R.W. and Torrissen, O.J., 1992. Synthetic astaxanthin deposition in pan-size coho salmon (Oncorhynchus kisutch). Aquaculture, 104: 105- 119. https://doi.org/10.1016/00448486(92)90141-7

Steine, G., Alfnes, F. and Bencze. 2005. The effect of color on consumer WTP for farmed salmon. Mar. Resour. Econ., 20: 211-219. https://doi.org/10.1086/ mre.20.2.42629470

Storebakken, T., Foss, P., Schiedt, K., Austreng, E., Liaaen-Jensen, S. and Manz, U., 1987. Carotenoids in diets for salmonids IV. Pigmentation of Atlantic salmon with astaxanthin, astaxanthin dipalmitate and canthaxanthin. Aquaculture, 65: 279- 292. https://doi.org/10.1016/0044-8486(87)90241-9

Storebakken, T. and No, H.K., 1992. Pigmentation of rainbow trout. Aquaculture, 100: 209- 229. https:// doi.org/10.1016/0044-8486(92)90372-R

Storebakken, T., Sørensen, M., Bjerkeng, B. and Hiu, S., 2004. Utilisation of astaxanthin from the red yeast, Xanthophylls dendrorhus, in rainbow trout, Oncorhynchus mykiss: Effects of enzymatic cell wall disruption and extrusion temperature. Aquaculture, 236: 391-403. https:// doi.org/10.1016/j.aquaculture.2003.10.035

Sylvia, G., Morrissey, M.T., Graham, T. and Garcia, S., 1995. Organoleptic qualities of farmed and wild salmon. J. Aquat. Fd. Prod. Technol., 4: 51- 64. https://doi.org/10.1300/J030v04n01_04 
Torrissen, O.J. and Naevdal, G., 1984. Pigmentation of salmonids- genetical variation in carotenoid deposition in rainbow trout. Aquaculture, 38: 59- 66. https://doi.org/10.1016/0044-8486(84)90137-6

Torrissen, O.J., 1985. Pigmentation of salmonids: factors affecting carotenoid deposition in rainbow trout (Salmo gairdneri). Aquaculture, 46: 133- 142. https://doi.org/10.1016/0044-8486(85)90197-8

Torrissen, O.J., Hardy, R.W. and Shearer, K.D., 1989. Pigmentation of salmonids-carotenoid deposition and metabolism. Rev. Aquat. Sci., 1: 209- 225.

Torrissen, O.J., 1995. Strategies for salmonid pigmentation. J. appl. Ichthyol., 11: 276-281. https:// doi.org/10.1111/j.1439-0426.1995.tb00027.x

Yeşilayer, N., Aral, O., Karsli, Z., Öz, M., Karaçuha,
A. and Yağc1, F., 2011. The effects of different carotenoid sources on skin pigmentation of goldfish (Carassius auratus). Isr. J. Aquacult-Bamidgeh, 63: $1-9$.

Yeşilayer N. and M. Erdem. 2011. Effects of oleoresin paprika (Capsicum annum) and synthetic carotenoids (cantahaxanthin and astaxanthin) on pigmentation levels and growth in rainbow trout (Oncorhynchus mykiss). J. Anim. Vet. Adv., 10: 1875- 1882. https:// doi.org/10.3923/javaa.2011.1875.1882

Yeşilayer N. and N. Genç. 2013. Comparison of proximate and fatty acid compositions of wild brown trout and farmed rainbow trout. S. Afr. J. Anim. Sci., 43: 8997. https://doi.org/10.4314/sajas.v43i1.11 